\title{
Are cyanobacteria total, specific and trait abundance regulated by the same environmental variables?
}

\author{
Diego Frau ${ }^{1, *}$, Paula de Tezanos Pinto ${ }^{2}$ and Gisela Mayora ${ }^{1}$ \\ ${ }^{1}$ Laboratorio de Plancton, Instituto Nacional de Limnología (CONICET-UNL), Ciudad Universitaria Paraje El Pozo, \\ 3000 Santa Fe, Argentina \\ 2 Departamento de Ecología, Genética y Evolución, IEGEBA (UBA-CONICET), Facultad de Ciencias Exactas y Naturales, \\ UBA Buenos Aires, Argentina
}

Received: 28 July 2017; Accepted: 22 November 2017

\begin{abstract}
In this study we analyzed if cyanobacteria total, specific and trait abundance are regulated by the same environmental variables in a Neotropical urban lake that recurrently suffers harmful cyanobacteria blooms. To assess the predictor variables for cyanobacteria total and species density we performed a multiple regression (GLM) and a redundancy analysis (RDA), respectively. Temperature and oxygen were the main predictor variables for both total and species abundance. Conductivity was an exclusive predictor for cyanobacteria total density (GLM) and light availability $\left(Z_{\mathrm{d}}: Z_{\mathrm{eu}}\right)$ for species abundance (RDA). Nutrients were unnoticeable predictor variables for both. Cyanobacteria blooms showed high recurrence $(8$ blooms in 12 months) and occurred within $17-28^{\circ} \mathrm{C}$. Blooms were mostly dominated by one species, and less frequently co-dominated by two species. These blooms were more recurrently dominated by dispersive non-fixing filamentous species (mainly Raphidiopsis curvata) linked to lower light availability. Less frequently, blooms were dominated by filamentous nitrogen fixers which develop scum blooms (mainly Anabaenopsis arnoldii) related to better light availability and lower dissolved oxygen concentration. The nitrogen fixing species showed high heterocyte density, suggesting nitrogen fixing behavior and probably giving this an advantage when inorganic nitrogen was low. Our results indicate that in absence of nutrients limitation, cyanobacteria total and species abundance can be regulated by different environmental variables. These results also show that species phylogenetically related ( $R$. curvata and $A$. arnoldii) can respond differently to the prevailing environmental variables; highlighting the importance of considering cyanobacteria to a specific level when assessing their possible control factors.
\end{abstract}

Keywords: cyanobacteria / temperature / light availability / oxygen concentration

\section{Introduction}

Massive cyanobacteria growths constitute harmful algal blooms which can cause severe economic (Merel et al., 2013), ecological (Huisman et al., 2005), and health problems (Drobac et al., 2013Carmichael and Boyer, 2016). The scenarios of global climate change forecast enhanced frequency and magnitude of such blooms, mostly due to increased global temperatures and eutrophication (Paerl and Huisman, 2009; Paerl and Otten, 2013). Thus, currently, great efforts are being invested in mitigating, preventing and predicting cyanobacteria harmful blooms (Paerl et al., 2016).

A wealth of studies has helped to unravel the main factors which control cyanobacteria biomass. That is, blooms are

*Corresponding author: diegofrau@gmail.com mostly favored by high nutrients, high temperatures, high water stability and high water residence time O'Neil et al., 2012; Paerl et al., 2016), among other factors. Although many studies have assessed the responses of particular species to particular environmental triggers (e.g. de Tezanos Pinto and Litchman, 2010a; Bonilla et al., 2012); or reviewed the ecophysiological responses of nuisance species (Burford et al., 2016; Cires and Ballot, 2016; Gobler et al., 2016; Li et al., 2016), it is still unclear if the environmental variables that drive cyanobacteria total abundance affect species and trait abundance in a similar way. The latter would be the case if blooms were composed by the same species or if all species within a bloom responded in the same way to environmental triggers. Nevertheless, cyanobacteria capable of developing harmful blooms encompass a diverse group of organisms (three taxonomical Orders: Chroococcales, Oscillatoriales and Nostocales) and of ecological traits (morphologies, 


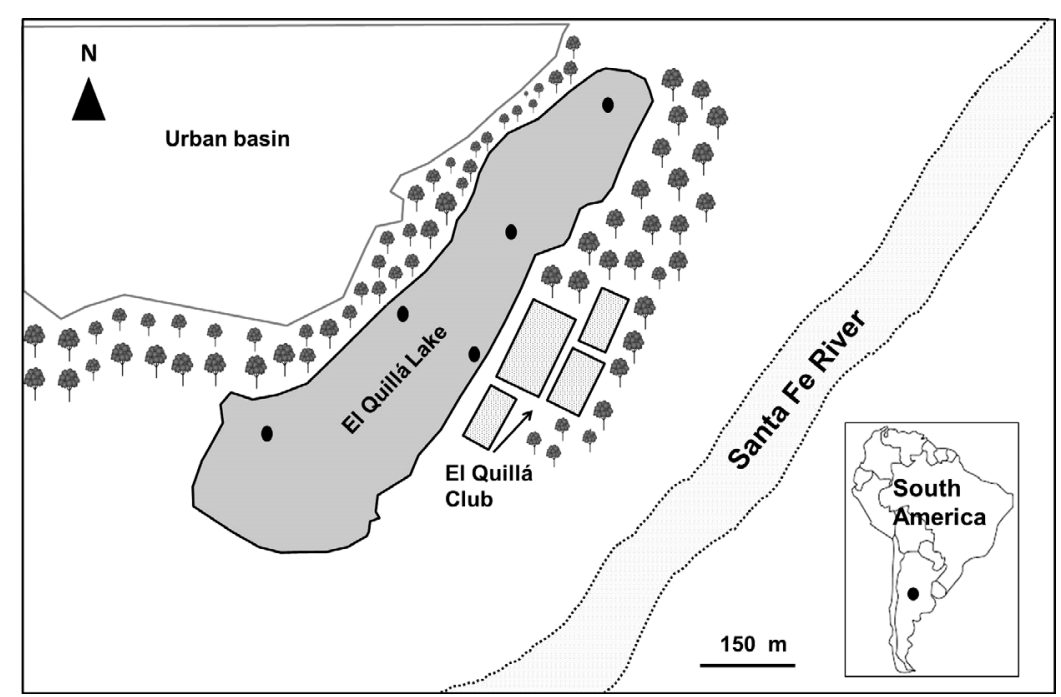

Fig. 1. Quillá Lake study area. Dots denote the 5 sampling sites, which were sampled monthly throughout a year $(n=5$ sites $\times 12$ months $=60$ samples).

physiologies and life cycles). Because the traits that may help cyanobacteria dominance are not shared by all taxa, different species may respond differently to environmental variables. For example, Dolman et al. (2012) analyzed the importance of nitrogen versus phosphorus in explaining total and specific cyanobacterial biovolume in 102 German lakes, and found bloom-forming species may display diverse responses to differential $\mathrm{N}$ versus $\mathrm{P}$ concentrations, even within species that shared the trait of nitrogen fixation. Also, Gobler et al. (2016) showed that beyond total cyanobacteria biomass, $\mathrm{N}$ loading selectively promoted the abundance of non-fixing cyanobacteria (Microcystis and Planktothrix). Hence, Cyanobacteria should not be treated as a single group when considering the effects of changes in nutrient loading on phytoplankton community structure (Dolman et al., 2012). This probably also happens along light gradients, as certain cyanobacteria bloom mostly forming surface scums (e.g. Dolichospermum, Aphanizomenon, Microcystis) while others are usually found throughout the water column (e.g. Planktothrix, Limnotrix) (Chorus and Bartram, 1999; Paerl et al., 2016).

Exploring the effects of varying chemical, physical and biological variables beyond total biomass will broaden our understanding of the ecology of the group, and our abilities to forecast bloom composition in different scenarios. In this paper we assessed cyanobacteria total bloom, species and trait abundance in a Neotropical shallow lake which recurrently suffers cyanobacteria blooms throughout one year. We aimed to answer if the abundance of total cyanobacteria and the abundance of the species which develop blooms (and its ecological traits) are regulated by similar chemical and physical variables.

\section{Material and methods}

\subsection{Study area}

The shallow urban Lake Quillá $\left(31^{\circ} 39^{\prime} \mathrm{S}, 60^{\circ} 42^{\prime} \mathrm{W}\right.$, Argentina) has a surface of 12 hectares and its basin has flatbed topography, a mean depth of $2.7 \mathrm{~m}$ and a maximum depth of $4 \mathrm{~m}$ in its central area (Fig. 1). This lake has a high recreational value as it is used for rowing, mostly during the warm seasons, recurrently suffering cyanobacteria blooms throughout the year.

\subsection{Sampling and assessment of environmental variables and cyanobacteria}

From June 2014 to May 2015, several environmental variables were monthly measured in situ in five sampling points (four littoral and one limnetic) to encompass the spatial heterogeneity produced by the effect of wind and the characteristics of the littoral (presence of vegetation and shorter water column) and the limnetic area (without vegetation and deeper water column) ( $n=60$ samples) (Fig. 1). The physical-chemical variables considered were: temperature $\left({ }^{\circ} \mathrm{C}\right)$, dissolved oxygen (DO) $\left(\mathrm{mg} \mathrm{L}^{-1}\right.$ and saturation percentage), $\mathrm{pH}$ and conductivity $\left(\mu \mathrm{S} \mathrm{cm}^{-1}\right)$, using HANNA multiparameter probes. Depth $\left(Z_{\mathrm{d}}\right)$ (meters) was measured with an ultrasonic probe. The photic zone $\left(Z_{\mathrm{eu}}\right)$ was estimated according to Koenings and Edmundson (1991) for turbid environments as $Z_{\mathrm{eu}}=$ Secchi depth (SD) $(\mathrm{m}) \times 3.5$. The $Z_{\mathrm{d}}: Z_{\text {eu }}$ ratio was calculated as a measure of light availability in the water column. High values of this ratio indicate that the relative amount of time that phytoplankton spends in darkness increases (Reynolds, 1984). Water volume $\left(\mathrm{m}^{3}\right)$ entering the lake was estimated using the criteria suggested by UNESCO (2006). Water samples for dissolved inorganic and total nutrient concentration: nitrate + nitrite $(\mathrm{N}$ $\left.\mathrm{NO}_{3}{ }^{-}+\mathrm{N}-\mathrm{NO}_{2}{ }^{-}\right)$, ammonium $\left(\mathrm{N}-\mathrm{NH}_{4}{ }^{+}\right)$, soluble reactive phosphorus (SRP), total phosphorus (TP) and total nitrogen (TN) were taken using $1 \mathrm{~L}$ bottles. Concentration estimations $\left(\mu \mathrm{g} \mathrm{L}^{-1}\right)$ were done in laboratory following the protocols indicated in APHA (2005).

Phytoplankton samples were also collected monthly throughout a year (June 2014 to May 2015) at the same sampling points (four littoral and one limnetic) considered in physico-chemical sampling ( $n=60$ samples) (Fig. 1). In each 
Table 1. Mean values of the environmental variables analyzed, sorted by seasons. Values within parentheses denote the standard deviation (for each season and variable $n=5$ sites $\times 3$ months $=15$, total $n$ for each variable $=60$ ).

\begin{tabular}{lllll}
\hline & Winter & Spring & Summer & Autumn \\
\hline Temp. $\left({ }^{\circ} \mathrm{C}\right)$ & $15.0( \pm 0.7)$ & $19.4( \pm 1.8)$ & $27.3( \pm 0.7)$ & $24.0( \pm 3.1)$ \\
pH & $7.4( \pm 0.4)$ & $7.6( \pm 0.7)$ & $7.7( \pm 0.5)$ & $7.7( \pm 0.6)$ \\
Cond $\left(\mu \mathrm{S} \mathrm{cm}^{-1}\right)$ & $2447.0( \pm 774.4)$ & $3380.0( \pm 366.8)$ & $3296.3( \pm 373)$ & $5918.8( \pm 4485)$ \\
$Z_{\mathrm{d}: Z_{\text {eu }}}$ & $1.3( \pm 0.8)$ & $1.1( \pm 1.1)$ & $1.1( \pm 0.9)$ & $1.4( \pm 1.2)$ \\
DO $\left(\mathrm{mg} \mathrm{L}^{-1}\right)$ & $14.2( \pm 3.8)$ & $12.1( \pm 2.3)$ & $8.8( \pm 2.9)$ & $9.8( \pm 1.1)$ \\
sat. DO $(\%)$ & $100( \pm 19)$ & $91( \pm 32)$ & $79( \pm 9)$ & $84( \pm 47)$ \\
Water vol. $\left(\mathrm{m}^{3}\right)$ & $5687.9( \pm 2724.07)$ & $8405.5( \pm 4098.9)$ & $20350.1( \pm 12511.3)$ & $23383.7( \pm 26590.7)$ \\
TN $\left(\mu \mathrm{g} \mathrm{L}^{-1}\right)$ & $2475.3( \pm 1870.7)$ & $1326.4( \pm 837.4)$ & $959.3( \pm 216.1)$ & $894.7( \pm 155.8)$ \\
DIN $\left(\mu \mathrm{g} \mathrm{L}^{-1}\right)$ & $2083.7( \pm 1602.96)$ & $152.2( \pm 104.48)$ & $120.4( \pm 102.68)$ & $195.8( \pm 218.33)$ \\
TP $\left(\mu \mathrm{g} \mathrm{L}^{-1}\right)$ & $212.1( \pm 25.1)$ & $269.2( \pm 104.3)$ & $357.1( \pm 125.6)$ & $400.6( \pm 157.3)$ \\
SRP $\left(\mu \mathrm{g} \mathrm{L}^{-1}\right)$ & $109.9( \pm 51.75)$ & $66.0( \pm 52.25)$ & $97.4( \pm 63.96)$ & $89.9( \pm 31.69)$ \\
\hline
\end{tabular}

sampling site and occasion phytoplankton samples were collected using $100 \mathrm{~mL}$ bottles, and immediately fixed with $1 \%$ acidified Lugol solution. Phytoplankton quantitative analyses were conducted following the Utermöhl (1958) method and taxonomic identifications of cyanobacteria were carried out to the species level (whenever possible) using Komárek and Anagnostidis (1999, 2005) and Komárek (2013). Phytoplankton density was expressed as individuals per milliliter (ind $\mathrm{mL}^{-1}$ ).

Exclusively for cyanobacteria species, cell density (cell $\mathrm{mL}^{-1}$ ) was also calculated. For this, the mean number of cells per organism was estimated by counting the total number of cells in about 25 individuals (cell ind ${ }^{-1}$ ) of each species and multiplied by the density of individuals (ind $\mathrm{mL}^{-1}$ ). A bloom event was identified whenever cyanobacteria cell density surpassed 50000 cell $\mathrm{mL}^{-1}$. Though there is lack of consensus regarding what constitutes a cyanobacteria bloom (Smayda, 1997; Whitton and Potts, 2000; Reynolds, 2006), this arbitrary value $\left(\geq 50000\right.$ cell $\left.\mathrm{mL}^{-1}\right)$ lays between the first and second alert level for health risk established by the Health World Organization (up to 20000 and up to 100000 cyanobacteria cell $\mathrm{mL}^{-1}$, respectively). The species which reached bloom densities were sorted into the following traits: morphology (filament, colony, single cell), type of bloom developed (scum in the surface of the water body or dispersed throughout the water column) and capability to fix nitrogen. Trait sorting was based on updated literature, taxonomy and measurements performed with natural samples from Lake Quillá.

Blooms were classified as mono-specific when a single species dominated $(>65 \%)$ the total cyanobacteria density, and as poly-specific when more than one species contributed between $15 \%$ and $65 \%$ to the total cyanobacteria density. The same criterion was applied for assessing traits dominance. In particular, the nitrogen fixing behavior in taxa of the Order Nostocales was estimated by counting the number of heterocytes (cell where nitrogen fixation occurs) per filament (hets $\mathrm{fil}^{-1}$ ) in at least 25 individuals, and its average was then multiplied by the density (ind $\mathrm{mL}^{-1}$, where ind=filament). Heterocyte density (hets $\mathrm{mL}^{-1}$ ) was used as a proxy of nitrogen fixing activity, as indicated by de Tezanos Pinto and Litchman (2010b). The ratio of vegetative cell to heterocyte was also computed.

\subsection{Statistical analyses}

To assess the environmental variables which influenced total cyanobacteria abundance, a multiple regression model with Gaussian adjustment was run. This model was used after proving several environmental combinations. The best model was chosen according to its statistical significance and the Akaike Information Criterion (AIC). The density of total cyanobacteria during the whole sampling period $(n=60)$ was used as response variable. To assess the environmental variables which influenced the abundance of the cyanobacteria species which developed blooms, a Redundancy Analysis (RDA) was run. This method was used because the Detrended Correspondence Analysis (DCA) revealed that the gradient length of the response data was $<3$ (Lepš and Šmilauer, 1999). Only variables that had a variance inflation factor (VIF) less than 20 were considered in the RDA analysis (Lepš and Šmilauer, 1999). Environmental variables were considered predictive variables and were chosen with a forward selection. The densities (cell $\mathrm{mL}^{-1}$ ) of each cyanobacteria species which developed blooms were used as response variables. All statistical analyses were performed using the software CANOCO for windows v. 5.10 (ter Braak and Śmilauer, 2012).

\section{Results}

\subsection{Environmental and phytoplankton assemblage characterization}

The most rainy and hot seasons were summer and autumn $\left(564 \mathrm{~mm}-30^{\circ} \mathrm{C}\right.$ and $1085 \mathrm{~mm}-23^{\circ} \mathrm{C}$, respectively) while the least were winter and spring $\left(136 \mathrm{~mm}-14{ }^{\circ} \mathrm{C}\right.$ and $25 \mathrm{~mm}$ $-20^{\circ} \mathrm{C}$, respectively). Water temperature, water volume and TP concentration were higher in summer and autumn than in winter and spring (Tab. 1). The opposite pattern occurred for TN (Tab. 1). TN was between two fold to one order of magnitude higher than TP (Tab. 1). DIN and SRP fractions were very high in winter, but dropped to lower concentrations in spring, summer and autumn (Tab. 1). In the latter period, DIN concentrations were one order of magnitude lower than in winter (Tab. 1). SRP concentrations, however, were always above $14 \mu \mathrm{g} \mathrm{L}^{-1}$, with mean values ranging from 66 to $109 \mu \mathrm{gL}^{-1}$ (Tab. 1). Dissolved oxygen values were always 


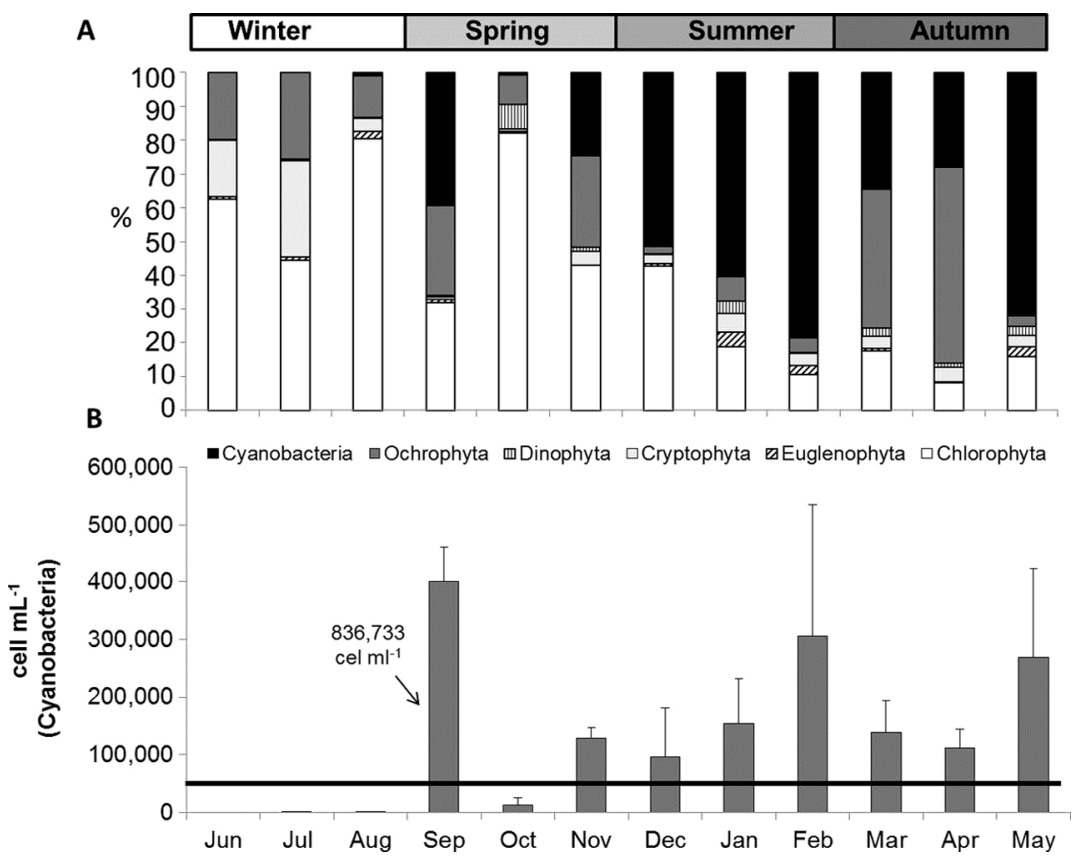

Fig. 2. Relative phytoplankton community composition (A) and absolute (cells $\mathrm{mL}^{-1}$ ) abundance of total cyanobacteria species (vertical lines indicate standard deviation) throughout the study period (the horizontal line denotes the threshold of $>50000$ cell mL $\mathrm{msed}^{-1}$ in the study to consider a cyanobacteria bloom) (B).

Table 2. Cyanobacteria species found during the study period. Within bloom forming species the following ecological traits are indicated in bold: $\mathrm{C}=$ colonial morphology, $\mathrm{F}=$ filamentous morphology, $\mathrm{S}=$ scum forming bloom type, $\mathrm{D}=$ dispersive bloom type, and $\mathrm{N}=$ capability to develop heterocytes, the specialized cell where nitrogen fixation occurs.

Cyanobacteria

\section{Chroococcales}

Aphanocapsa delicatissima Wets and West

Aphanocapsa holsatica (Lemmermann) Cronberg et Komárek

Chroococcus minutus (Kützing) Nägeli

Coelomoron pusillum (Van Goor) Komárek

Merismopedia glauca (Ehrenberg) Kützing

Microcystis aeruginosa (Kützing) Kützing C, S

Microcystis natans Lemmermann ex Skuja

Microcystis smithii Komárek and Anagnostidis

Nostocales

Anabaenopsis arnoldii Aptekarj F, S, N

Dolichospermum circinale (Rabenh. ex Bornet and Flahault)F,

$\mathbf{S}, \mathbf{N}$

Raphidiopsis curvata Fritsch et. RichF, D

Raphidiopsis mediterranea Skuja

Oscillatoriales

Glaucospira laxissima $\mathrm{cf}$. West

Lyngbya sp.

Phormidium sp.

higher than $8 \mathrm{mg} \mathrm{L}^{-1}$ (Tab. 1); its concentrations were lower in autumn and summer compared to winter and spring. A similar pattern was observed for dissolved oxygen saturation (\% sat. DO) (Tab. 1). Conductivity was high and ranged in average from 2400 to $5900 \mu \mathrm{S} \mathrm{cm}^{-1} ; \mathrm{pH}$ remained rather neutral throughout the study period (Tab. 1 ). The $Z_{\mathrm{d}}: Z_{\text {eu }}$ ratio was, in average, higher than one across seasons, yet $Z_{\mathrm{d}}: Z_{\mathrm{eu}}$ also reached values of one within each season, as evidenced by the high standard deviation (Tab. 1).

Phytoplankton density was 4500 ind $\mathrm{mL}^{-1}$ during the winter season, but increased one order of magnitude $\left(>50000\right.$ ind $\left.\mathrm{mL}^{-1}\right)$ for most part of spring - in particular in September and October - and then dropped to about a half (18000 ind $\mathrm{mL}^{-1}$ ) throughout summer and autumn. During winter and spring the phytoplankton assemblage was dominated in density (ind $\mathrm{mL}^{-1}$ ) by Chlorophyta $(40-80 \%$ relative density), while in summer and autumn it was dominated by Cyanobacteria $(30-80 \%$ relative density) (Fig. 2A).

\subsection{Cyanobacteria dynamics throughout the study period}

The total number of phytoplankton species recorded throughout the studied period was 115. Out of the phytoplankton richness, 15 species were Cyanobacteria (Tab. 2). From the latter, 5 reached bloom densities $\left(>50000\right.$ cell $\left.\mathrm{mL}^{-1}\right)$ at least once during the studied period (Tab. 2). We recorded cyanobacteria blooms in 8 out of the 12 months analyzed, throughout spring (except in October), summer and autumn, with a magnitude of 100000 800000 cell mL ${ }^{-1}$ (mode 10000 cell mL ${ }^{-1}$ ) (Fig. 2B). High variability in abundance was registered during seasons, especially during February and May (Fig. 2B), reflecting a heterogeneous distribution of blooms in the lake. In winter 

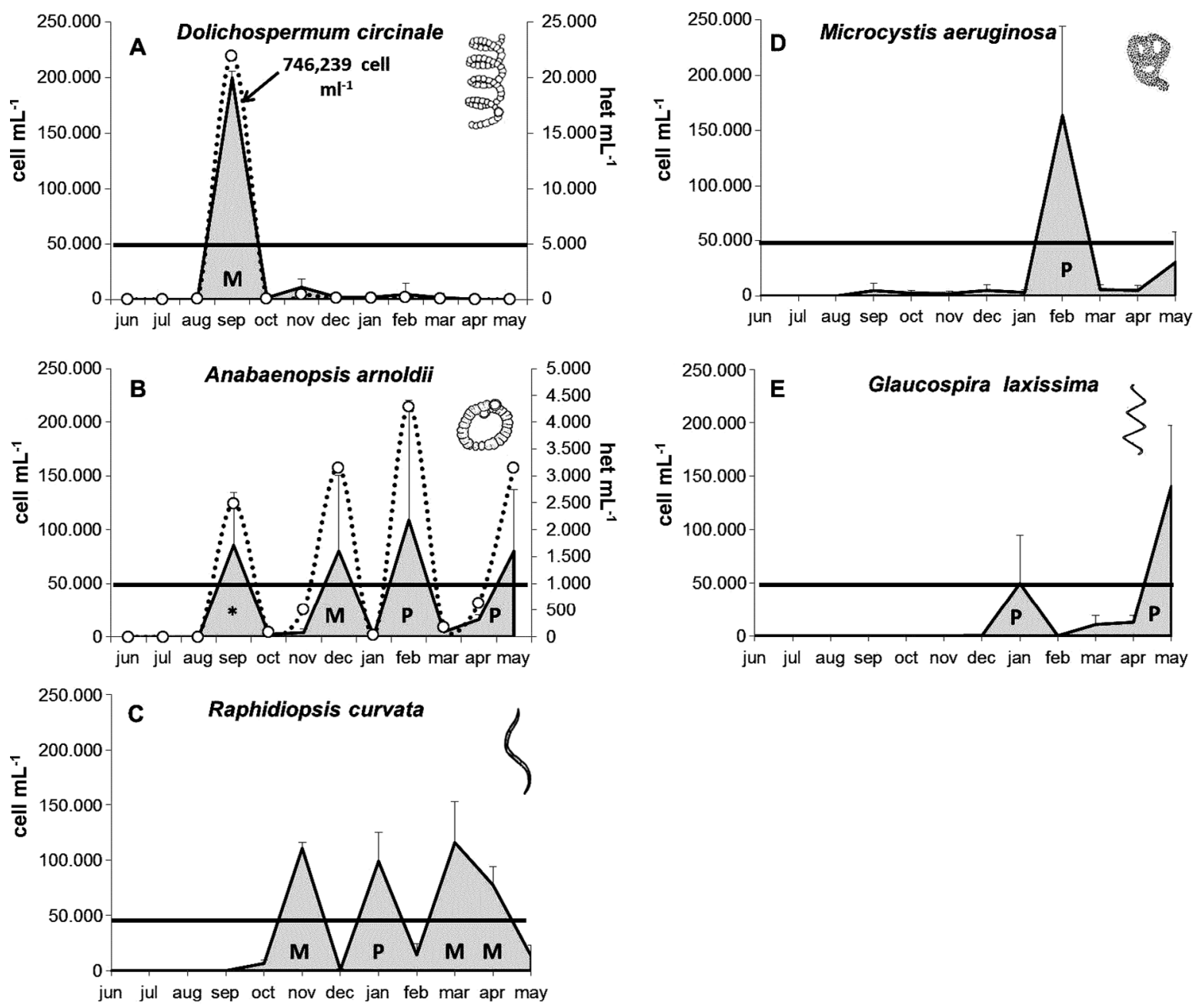

Fig. 3. Monthly cyanobacteria absolute abundance $\left(\right.$ cell $\mathrm{mL}^{-1}$ ) of the species which bloomed throughout the study period (vertical lines indicate standard deviation). For the nitrogen fixing cyanobacteria Dolichospermum circinale and Anabaenopsis arnoldii the secondary axis shows heterocyte abundance (het $\mathrm{mL}^{-1}$, dotted line). The horizontal line denotes the threshold of $>50000$ cell $\mathrm{mL}^{-1}$ used in the study to consider a cyanobacteria bloom. $M=$ Mono-specific bloom, $P=$ poly-specific bloom. $* A$. arnoldii surpassed the threshold of $50000 \mathrm{cell}^{\mathrm{mL}} \mathrm{m}^{-1}$, yet it contributed with less than $15 \%$ of total bloom abundance in September.

there was lack of cyanobacteria blooms and its absolute and relative densities were almost zero (Fig. 2A and B).

Regarding bloom dominance patterns, these were most of the times ( 5 out of the 8 blooms) dominated by a single species (mono-specific). Less frequently blooms (3 out of the 8 blooms) were co-dominated by two species (poly-specific), without following a straightforward temporal pattern (Fig. 3). The dominant species in the assemblage was rarely the same across sampling periods (Fig. 3).

The five mono-specific blooms were composed either by: Dolichospermum circinale $(90 \%$ of total cyanobacteria density, in September), Anabaenopsis arnoldii (84\% of total cyanobacteria density, in December) and Raphidiopsis curvata $(88 \%, 80 \%$ and $70 \%$ of total cyanobacteria density in November, March and April, respectively). The three polyspecific blooms occurred in: January $(60 \%$ R. curvata and $33 \%$ Glaucospira laxissima), February (55\% Microcystis aeruginosa and 38\% A. arnoldii), and May (52\% G. laxissima and $30 \%$ A. arnoldii) (Fig. 3). In September, D. circinale reached the maximum bloom density registered $\left(746279 \mathrm{cell} \mathrm{mL}^{-1}\right)$
(Fig. 3A). While A. arnoldii (Fig. 3B) reached the threshold of absolute abundance considered as a bloom; its relative contribution to total cyanobacteria abundance in September was lower than $15 \%$. Hence, this case September sampling was excluded from the assessment of bloom dominance pattern (mono and/or polyspecific).

$R$. curvata and $A$. arnoldii were the species with the highest bloom recurrence; each species reached bloom densities four times throughout the study, with similar magnitude (range: $75000-100000$ cell $\mathrm{mL}^{-1}$ ) (Fig. 3). In A. arnoldii, only one out of the four blooms was mono-specific (Fig. 3B), whereas in $R$. curvata three out of the four blooms were mono-specific (Fig. 3C). These species were the only ones which developed both mono-specific and poly-specific blooms (Fig. 3). Their absolute densities showed opposing patterns and never codominated in a poly-specific bloom (Fig. 3).

Regarding the trait of nitrogen fixation, $D$. circinale and $A$. arnoldii developed heterocytes during blooms: in the $D$. circinale bloom, heterocyte density was very high (ca. 20000 hets $\mathrm{mL}^{-1}$ ) whereas in the latter it was much lower 
Table 3. Trait characterization of the cyanobacteria blooms: morphology, eco-strategy and nitrogen fixing ability are indicated. Key: Dolichospermum circinale (Dolich.), Anabaenopsis arnoldii (Anabaen.), Raphidiopsis curvata (Raphid.), Microcystis aeruginosa (Microcys.), Glaucospira laxissima (Glaucos.).

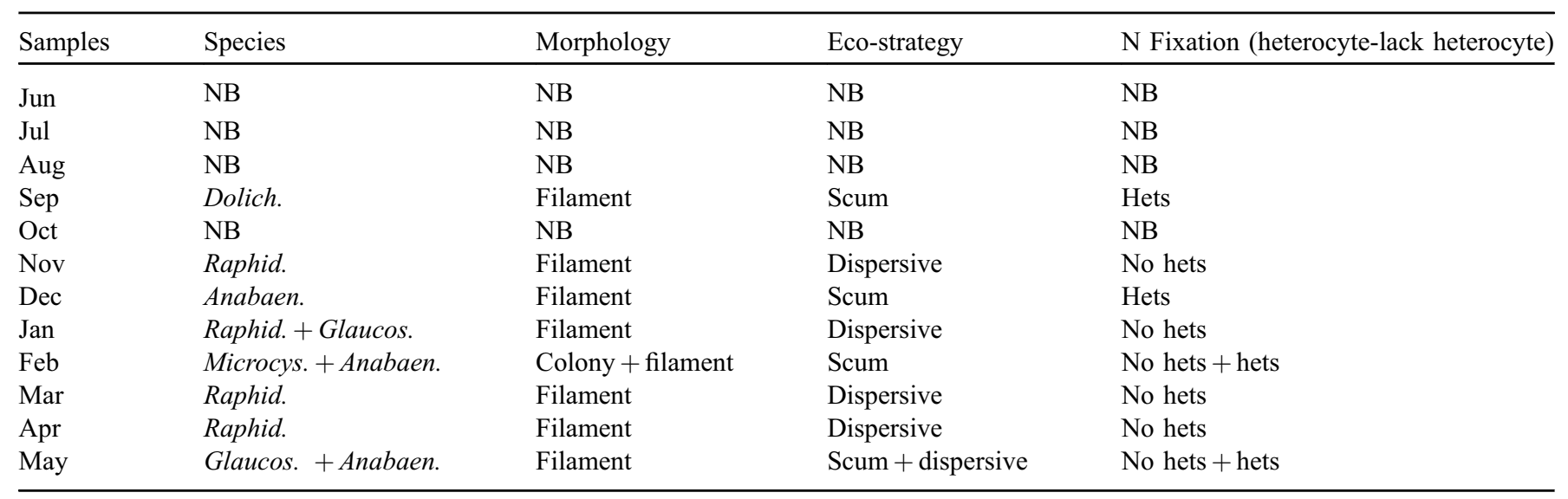

$\mathrm{NB}=$ No bloom event.

Table 4. Multiple regression model (GLM) using total Cyanobacteria abundance as response variable. Statistically significant values $(p<0.05)$ are indicated in bold.

\begin{tabular}{lllll}
\hline Term & $b$ & $S E$ & $T$ & $p(T)$ \\
\hline Intercept) & 0.845707 & 0.9568586 & 0.88 & 0.38078 \\
Temp & $\mathbf{0 . 1 6 2 7 8 2}$ & 0.03084941 & $\mathbf{5 . 2 8}$ & $<\mathbf{0 . 0 0 0 0 1}$ \\
pH & -0.00150902 & 0.00107495 & -1.4 & 0.16621 \\
Cond & $\mathbf{0 . 0 0 0 1 3 8 5 1}$ & $4.24 \mathrm{E}^{-05}$ & $\mathbf{3 . 2 7}$ & -1.2 \\
$Z_{\text {mix }}: Z_{\text {eu }}$ & -0.126665 & 0.1037133 & $-\mathbf{3 . 4}$ & 0.22738 \\
DO & $-\mathbf{0 . 1 3 9 1}$ & 0.04088931 & -1.5 & $\mathbf{0 . 0 0 1 2 8}$ \\
WT & $-1.36 \mathrm{E}^{-05}$ & $9.14 \mathrm{E}^{-06}$ & 0.14313 \\
\hline
\end{tabular}

$\mathrm{WT}=$ Water volume.

(2500-4500 hets $\mathrm{mL}^{-1}$ ) (Fig. 3A, B). Nevertheless, both species showed similar ratio of vegetative to heterocyte cells (about 25 vegetative cells per heterocyte).

Despite differences in species composition within and across blooms (Fig. 3), blooms were mostly (7 out of the 8 blooms) of filamentous morphology (Tab. 3). Blooms were dominated by species capable of either dispersive development ( $R$. curvata and $G$. laxissima, in 4 out of 8 blooms) or scumtype development (D. circinale, $A$. arnoldii and/or $M$. aeruginosa in 3 out of 8 blooms), without following a straightforward pattern (Tab. 3). One bloom was co-dominated by dispersive and scum forming species (Tab. 3). The trait of nitrogen fixation (heterocyte presence) was dominant in 2 of the 8 blooms (Tab. 3).

\subsection{Environmental variables which affected cyanobacteria total and species abundance}

The multiple regression model was statistically significant $(F=21.08, p<0.001)$ and 3 variables $(p<0.05$ for each one) out of 6 variables analyzed (Tab. 4) explained $70.5 \%$ of the changes observed in total cyanobacteria abundance. In the model, cyanobacteria abundance was positively linked with temperature and conductivity, but negatively linked with dissolved oxygen (Tab. 4). The RDA analysis (Fig. 4), run with the density of the 5 Cyanobacteria species which developed blooms was statistically significant $(F=3.5, p=0.001)$ and explained $43.8 \%$ of total variation. The first and second axis of the RDA explained the $81.2 \%$ and $16.6 \%$, respectively. The significant variables were: temperature, $Z_{\mathrm{d}}: Z_{\mathrm{eu}}$ ratio and dissolved oxygen. Temperature explained $30.5 \%$ of total variance $(F=17.9, p=0.001)$ and had a positive association with all cyanobacteria species, especially with $M$. aeruginosa and $G$. laxissima (Fig. 4). Dissolved oxygen $(5.3 \%, F=2.9$, $p=0.02$ ) had a negative link with all cyanobacteria species, especially with $A$. arnoldii and $D$. circinale. The $Z_{\mathrm{d}}: Z_{\text {eu }}$ ratio (5.9\%, $F=2.2, p=0.048)$ showed a high and negative association with the densities of $D$. circinale and $A$. arnoldii (both developed scum type blooms), but showed a strong an positive link with the densities of $R$. curvata (developed dispersive type blooms).

\section{Discussion}

\subsection{Controlling factors of cyanobacteria total abundance}

Cyanobacteria blooms were recurrent throughout spring, summer and autumn with high magnitude (always surpassed 


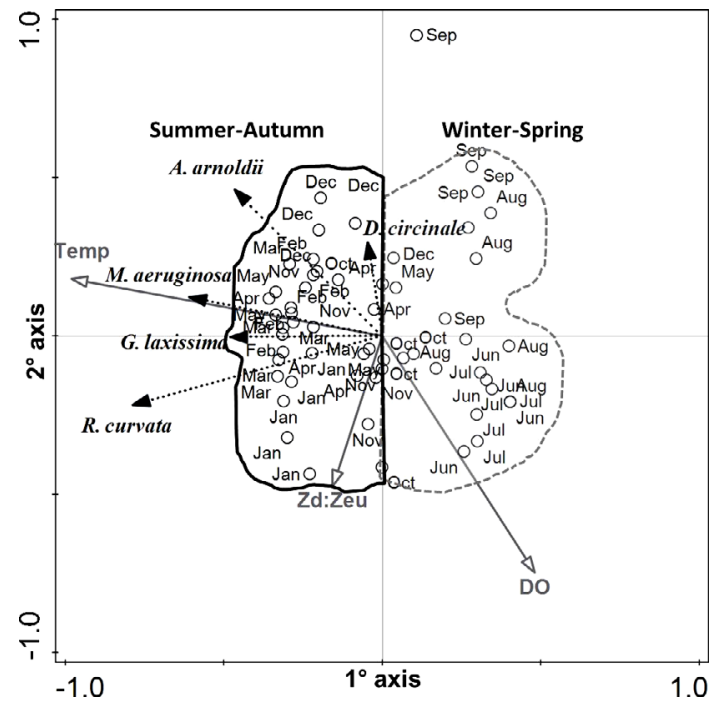

Fig. 4. Redundancy plot analysis. Response variables (abundance of each of the cyanobacteria species which developed blooms), predictor variables: temperature (Temp), depth:euphotic zone ratio $\left(Z_{\mathrm{d}}: Z_{\mathrm{eu}}\right)$, and dissolved oxygen concentration (DO).

the second alert level established by the World Health Organization (WHO, 2003) for drinking water and recreational risk assessment). Total cyanobacteria density was positively linked with increasing temperature and conductivity, but negatively linked with high dissolved oxygen. It is well acknowledged that increased temperature favors cyanobacteria blooms (Paerl and Huisman, 2009; O’Neil et al., 2012). In this study, cyanobacteria blooms occurred only when temperature was higher than $17^{\circ} \mathrm{C}$; the threshold was lower than reported elsewhere (e.g. Havens, $\left.2008,>20^{\circ} \mathrm{C}\right)$. Regarding the effects of conductivity in promoting cyanobacteria abundance, it is known that several cyanobacteria species are well adapted to high ion concentrations (e.g. Oren, 2000; Komárek and Johansen, 2015). The genera registered during high conductivity periods thrive well at high conductivity, including: Raphidiopsis (Chellappa and Medeiros Costa, 2003), Anabaenopsis (Malone et al., 2012), Microcystis (Tonk et al., 2007) and Glaucospira (Santos and Sant'Anna, 2010). In this lake, conductivity values increased with water volume during summer and autumn, suggesting an ionic contribution through either underground or superficial runoff water since nutrient concentrations showed lack of significant correlation with conductivity values ( $p>0.05$ for both). The negative relation between dissolved oxygen and total cyanobacteria abundance was probably related with the effect of temperature on gas dissolution.

\subsection{Environmental variables affecting the abundance of cyanobacteria species and traits}

The environmental variables that affected cyanobacteria species abundance were temperature, dissolved oxygen concentration and $Z_{\mathrm{d}}: Z_{\mathrm{eu}}$ ratio. Temperature and dissolved oxygen were also predictor variables for total cyanobacteria abundance. The temporal distribution of the species which developed blooms may, at least in part, be explained by their temperature growth optimum. For example, $M$. aeruginosa only bloomed at high temperatures $\left(\sim 27^{\circ} \mathrm{C}\right)$; this is consistent with previous studies which reported optimum growth for this genus between 25 and $35^{\circ} \mathrm{C}$ (Nalewajko and Murphy, 2001; Lürling et al., 2013). However, D. circinale bloomed at much lower temperatures $\left(\sim 17^{\circ} \mathrm{C}\right)$, in accordance with what was reported in laboratory experiments by Zapomělová et al. (2008). A. arnoldii and $R$. curvata bloomed at a wider temperature range (from 17 to 27 and $21-27^{\circ} \mathrm{C}$, respectively). The range found for $R$. curvata agrees with the results found by $\mathrm{Li}$ et al. (2008) (from 10 to $35^{\circ} \mathrm{C}$ ). The coincidence of temperature as a predictor variable for total and species abundance reflects that cyanobacteria have high temperature optima (median ca. $27^{\circ} \mathrm{C}$, Lürling et al., 2013). It also suggests that within the range of temperature optima, different species have particular growth optima values.

For this hyper-eutrophic lake (mean range of $\mathrm{TP}=200$ $400 \mu \mathrm{gL}^{-1}$ and $\mathrm{TN}=890-2500 \mu \mathrm{g} \mathrm{L}^{-1}$ ) soluble reactive phosphorus concentration was always above limiting concentrations for phytoplankton development $\left(<5 \mu \mathrm{gL}^{-1}\right.$, Reynolds, 2006). Dissolved inorganic nitrogen (DIN) despite been above limiting concentrations $\left(<100 \mu \mathrm{g} \mathrm{L}^{-1}\right.$, Reynolds, 2006), recurrently reached limiting concentrations as can be inferred by the large variation observed in the mean values (see Tab. 1). This great variation, however, could be explained by the large concentrations of total nitrogen $(\mathrm{TN})$ registered with low DIN concentrations.

Blooms were mostly dominated by one species or codominated by two species. Dominance patterns changed without following a straightforward temporal pattern, which may relate to the different $Z_{\mathrm{d}}: Z_{\text {eu }}$ ratios (light availability) which was a significant variable in the RDA analysis. Reynolds (1997) stated that species morphologically attenuated grow under sub-ideal conditions of light. The predominance of filamentous forms probably reflects the periodic light restriction for phytoplankton in this water body. Also, blooms were mostly of disperse type, and less frequently of scum forming type. When the water is stagnant, buoyant Cyanobacteria accumulate in the surface, whereas when there is turbulence and the water is mixed, species are evenly distributed throughout the water column (Paerl and Huisman, 2009).

The trait of nitrogen fixation (expressed in D. circinale and A. arnoldii) was dominant with better light availability, low DIN concentration and low dissolved oxygen concentration. This result may reflect the high dependence of light and anoxic conditions for nitrogen fixation. It is acknowledged that the rates of nitrogen fixation increase with light levels (Mugidde et al., 2003; Agawin et al., 2007) and poor oxygen conditions since it inhibits or reduce nitrogenase activity (enzyme responsible of nitrogen fixation) (Fay, 1992). These results are consistent with laboratory experiments which showed that in the absence of nitrogen supply, nitrogen fixation was about three times higher in light sufficiency than in light limitation (de Tezanos Pinto and Litchman, 2010a).

In this study, $R$. curvata and $A$. arnoldii bloomed with higher recurrence. Though these species share a monophyletic origin (order Nostocales, filamentous morphology) when $A$. arnoldii bloomed, $R$. curvata had very low densities, and vice versa. This opposite behavior may settle in their contrasting ecologies. $R$. curvata was dominant with high DIN concen- 
trations and low light availability while $A$. arnoldii, as a nitrogen fixer, was dominant with low DIN concentrations (high TN concentration) and high light availability. The relation low DIN and high $\mathrm{TN}$ could be indicating a high phytoplankton inorganic catching rate; which in this study may be favoring the growth of $A$. arnoldii as a nitrogen fixer. On the other hand, Raphidiopsis is the only genus within the order Nostocales that is unable to fix nitrogen, as it lacks part of the genes involved in the synthesis of the heterocytes and of the nitrogenase (Stucken et al., 2010). Therefore, we would not expect to find blooms of $R$. curvata in low DIN and high TN scenarios.

\section{Conclusions}

The results of the present study suggest that cyanobacteria total and species abundance are not necessary regulated by the same environmental variables. While cyanobacteria total and species abundance responded in a similar way to several environmental variables (especially temperature), certain variables affected in particular cyanobacteria total density (conductivity) and others the abundance of the species which developed blooms (light availability). We observed that closely related cyanobacteria (e.g. A. arnoldii and $R$. curvata, both from the order Nostocales), which were also the most recurrent species developing blooms, showed contrasting distributions in the studied environment. Their different ecologies, despite sharing a similar phylogeny, seem to be explained by a contrasting set of morphological and physiological traits (particularly related with light and nitrogen fixation). This highlights the importance of avoiding treating cyanobacteria as a single group when assessing the effects of environmental variables on the ecology of this group.

Acknowledgments. The authors thank Y. Battauz and C. De Bonis for their assistance in the field. We also want to thank to anonymous reviewers who improved the manuscript with their suggestions. This study was funded by the project SECTEI 2010-044-13 awarded by Secretaría de Ciencia y Técnica de la Provincia de Santa Fe (Argentina) and by the project PICT2013 no. 214-14 awarded by Agencia Nacional de Promoción Científica y Tecnológica. PTP acknowledges funding by CONICET PIP 0236.

\section{References}

Agawin NSR, Rabouille S, Veldhuis MJW, Servatius LS, Hol HM, van Overzee J, Huisman J. 2007. Competition and facilitation between unicellular nitrogen-fixing cyanobacteria and non-nitrogen-fixing phytoplankton species. Limnol Oceanogr 52: $2233-$ 2248.

APHA. 2005. Standard methods for the examination of water and wastewater, 21st edn. USA: American Public Health Association.

Bonilla S, Aubriot L, Soares CS, Gozález-Piana M, Fabre Huszar VL, Lürling M, Antoniades D, Padisák J, Kruk C. 2012. What drives the distribution of the Bloom-forming Cyanobacteria Planktothrix agardhii and Cylindrospermopsis raciborskii? FEMS Microbiol Ecol 79: 594-607.

Burford MA, Beardall J, Willis A, Orr PT, Magalhaes VT, Rangel LM, Azevedo SM, Neilan BA. 2016. Understanding the winning strategies used by the bloom-forming Cyanobacterium Cylindrospermopsis raciborskii. Harmful Algae 54: 44-53.

Carmichael WW, Boyer GL. 2016. Health impacts from cyanobacteria harmful algae blooms: implications for the North American Great Lakes. Harmful Algae 54: 194-212.

Chellappa NT, Medeiros CMA. 2003. Dominant and co-existing species of Cyanobacteria from a Eutrophicated reservoir of Rio Grande do Norte State, Brazil. Acta Oecol 24: S3-S10.

Chorus I, Bartram J. 1999. Toxic Cyanobacteria in water: a guide to their public health consequences, monitoring, and management. London: St Edmundsbury Press.

Cires S, Ballot A. 2016. A review of the phylogeny, ecology and taxonomy of bloom forming Aphanizomenon spp. and related species within the Nostocales (Cyanobacteria). Harmful Algae 54: 21-43.

de Tezanos Pinto P, Litchman EB. 2010a. Eco-physiological responses of nitrogen-fixing cyanobacteria to light. Hydrobiologia 639: 63-68.

de Tezanos PP, Litchman EA. 2010b. Interactive effects of N:P ratios and light on nitrogen-fixer abundance. Oikos 119: 567-575.

Dolman AM, Rücker J, Pick FR, Fastner J, Rohrlack T, Mischke U, Wiedner C. 2012. Cyanobacteria and Cyanotoxins: the influence of Nitrogen versus Phosphorus. PLoS One 7: 1-14.

Drobac D, Tokodi N, Simeunovic J, Baltic V, Stanic D, Svircev Z. 2013. A review: human exposure to cyanotoxins and their effects on health. Arh Hig Rada Toksikol 64: 305-316.

Fay P. 1992. Oxygen relations of nitrogen fixation in cyanobacteria. Microbiol Rev 56: 340-373.

Ferber LR, Levine SN, Lini A, Livingston GP. 2004. Do Cyanobacteria dominate in eutrophic lakes because they fix atmospheric nitrogen? Freshwater Biol 49: 690-708.

Gobler CJ, Burkholder JM, Davis TW, Harke MJ, Johengen T, Stow CA, Van de Waal DB. 2016. The dual role of nitrogen supply in controlling the growth and toxicity of cyanobacterial blooms. Harmful Algae 54: 87-97.

Havens K.E. 2008. Cyanobacterial blooms: effects on aquatic ecosystems. In: Hudnell HK, ed. Cyanobacterial harmful algal blooms: state of the science and research needs. Germany: Springer-Verlag, pp. 733-747.

Havens KE, Phlips EJ, Cichra MF, Li BL. 1998. Light availability as a possible regulator of cyanobacteria species composition in a shallow subtropical lake. Freshwater Biol 39: 547-556.

Huisman JM, Matthijs HCP, Visser PM. 2005. Harmful cyanobacteria. Aquatic ecology series 3. Dordrecht, The Netheralands: Springer.

Jacobsen BA, Simonsen P. 1993. Disturbance events affecting phytoplankton biomass, composition and species diversity in a shallow, eutrophic, temperate lake. Hydrobiologia 249: 9-14.

Koenings JP, Edmundson JA. 1991. Secchi disk and photometer estimates of light regimes in Alaskan lakes: effects of yellow color and turbidity. Limnol Oceanogr 36: 91-105.

Komárek J. 2013. Cyanoprokaryota.Teil/3rd part: heterocytous genera. In: Büdel , Gärtner L, Krienitz M, Chagerl M, eds. Süswasserflora von Mitteleuropa (Freshwater flora of Central Europe). Heidelberg, Berlin: Springer Spektrum.

Komárek J, Anagnostidis K. 1999. Cyanoprokaryota 1. Teil: Chroococcales. In: Ettl H, Gärtner G, Heynig H, Mollenhauer H, eds. Süßwasserflora von Mitteleuropa, Gustav Fischer, Boston, Lancaster (1999), p. 548.

Komárek J, Anagnostidis K. 2005. Cyanoprokaryota 2. Teil/ 2nd Part: Oscillatoriales. In: Büdel B, Krienitz L, Gärtner G, y Scnagerl M, eds. Süsswasserflora von Mitteleuropa, Elsevier/Spektrum, Heidelberg, p. 759. 
Komárek J, Johansen JR. 2015. Coccoid cyanobacteria. In: Wehr JD, Sheath RG, Kociolek RP, eds. Freshwater algae from North America: ecology and classification. Academic Press, United Kingdom, pp. 75-133.

Kromkamp J. 1987. Formation and functional significance of storage products in cyanobacteria. New Zeal J Mar Fresh Res 21: 457-465.

Lepš J, Šmilauer P. 1999. Multivariate analysis of ecological data. Czech Republic: University of South Bohemia Ceské Budejovice.

Li R, Wilhelm SW, Carmichael WW, Makoto M. 2008. Watanabe Polyphasic characterization of water bloom forming Raphidiopsis species (Cyanobacteria) from central China. Harmful Algae 7: $146-153$.

Li X, Dreher TW, Li R. 2016. An overview of diversity, occurrence, and toxin production of bloom-forming Dolichospermum (Anabaena) species. Harmful Algae 54: 54-68.

Lürling M, Eshetu F, Faassen EJ, Kosten S, Huszar VL. 2013. Comparison of cyanobacterial and green algal growth rates at different temperatures. Freshwater Biol 58: 552-559.

Malone CFS, Santos KRS, Sant'Anna CL. 2012. Algas e cianobactérias de ambientes extremos do Pantanal Brasileiro. Oecol Aust 16: 745-755.

Merel S, Walker D, Chicana R, Snyder S, Baurès E, Thomas O. 2013. State of knowledge and concerns on Cyanobacterial blooms and cyanotoxins. Environ Int 59: 303-327.

Mugidde R, Hecky RE, Hendzel LL, Taylor WD. 2003. Pelagic nitrogen fixation in lake Victoria (East Africa). J Gt Lakes Res 29: $76-88$.

Nalewajko C, Murphy TP. 2001. Effects of temperature, and availability of nitrogen and phosphorus on the abundance of Anabaena and Microcystis in Lake Biwa, Japan: an experimental approach. Limnology 2: 45-48.

O'Neil JM, Davis TW, Burford MA, Gobler CJ. 2012. The rise of harmful Cyanobacteria blooms: the potential roles of eutrophication and climate change. Harmful Algae 14: 313-334.

Oren A. 2000. Salt and brines. In: Whitton BA, Potts M, eds. The ecology of Cyanobacteria. The Netherlands: Kluer Academic Publishers, pp. 281-306.

Padisák J, Crossetti L, Naselli-Flores L. 2009. Use and misuse in the application of the phytoplankton functional classification: a critical review with updates. Hydrobiologia 621: 1-19.

Paerl HW, Huisman J. 2009. Climate change: a catalyst for global expansion of harmful Cyanobacterial blooms. Environ Microbiol Rep 1: 27-37.

Paerl HW, Otten TG. 2013. Harmful Cyanobacterial bloom: causes, consequences and controls. Microb Ecol 65: 995-1010.

Paerl HW, Gardner WS, Havens KE, Joyner AR, McCarthy MJ, Newell SE, Qin B, Scott JT. 2016. Mitigating cyanobacterial harmful algal blooms in aquatic ecosystems impacted by climate change and antropogenic nutrients. Harmful Algae 54: 213-222.

Reynolds CS. 1984. Phytoplankton periodicity: the interactions of form, function and environmental variability. Freshwater Biol 14: $111-142$

Reynolds CS. 1997. Vegetation Processes in the Pelagic: A model for Ecosystems Theory Excellence in Ecology, Ecology Institute, Odendorf.

Reynolds CS. 2006. The ecology of freshwater phytoplankton. Cambridge: Cambridge University Press.

Reynolds CS, Huszar VLM, Kruk C, Naselli-Flores L, Melo S. 2002. Towards a functional classification of the freshwater phytoplankton. J Plankton Res 24: 417-428.

Santos KRS, Sant'Anna CL. 2010. Cyanobacteria from different types of lakes ("salina", "salitrada" and "baía") representative of the Pantanal da Nhecolândia, MS, Brazil. Braz J Bot 33: 61.

Smayda TJ. 1997. What is a bloom? A commentary. Limnol Oceanogr 42: 1132-1136.

Stucken K, John U, Cembella A, Murillo AA, Soto-Liebe K, FuentesValdés JJ, Friedel M, Plominsky AM, Vásquez M, Glöckner G. 2010. The smallest known genomes of multicellular and toxic cyanobacteria: comparison, minimal gene sets for linked traits and the evolutionary implications. PLoS One 5: e9235.

ter Braak CJ, Šmilauer P. 2012. Canoco reference manual and user's guide: software for ordination, version 5.0. Ithaca: Microcomputer Power.

Tonk L, Bosch K, Visser PM, Huisman VJ. 2007. Salt tolerance of the harmful cyanobacterium Microcystis aeruginosa. Aquat Microb Ecol 46: 117-123.

UNESCO. 2006. Evaluación de los Recursos Hídricos. Elaboración del balance hídrico integral por cuencas hidrográficas. Documentos Técnicos del PHI-LAC, $\mathrm{N}^{\circ} 4$.

Utermöhl H. 1958. ZurVervollkommnung der quantitative Phytoplankton: methodik. Mitt Int Verein Theor Angew 9: 1-38.

Whitton BA, Potts M. 2000. The ecology of cyanobacteria. Their diversity in time and space. Dordrecht, London: Kluwer Academic Publishers.

Wiedner C, Rücker AJ, Brüggemann R, Nixdorf B. 2007. Climate change affects timing and size of populations of an invasive cyanobacterium in temperate regions. Oecologia 152: 473-484.

World Health Organization. 2003. World Health Report. Shaping the future. Geneva: World Health Organization, 204 p.

Zapomělová E, Hrouzek P, Reháková K, Šabacká M, Stibal CL, Komárková J, Lukesová A. 2008. Morphological variability in selected heterocystous Cyanobacterial strains as a response to varied temperature, light intensity and medium composition. Folia Microbiol 53: 333-341.

Cite this article as: Frau D, Pinto PdT, Mayora G. 2017. Are cyanobacteria total, specific and trait abundance regulated by the same environmental variables? Ann. Limnol. - Int. J. Lim. 54: 3 